\title{
Spatial variability in the epiphytic algal assemblages of Zostera marina seagrass beds
}

\author{
James E. Saunders ${ }^{1}$, Martin J. Attrill ${ }^{1, *}$, Stuart M. Shaw ${ }^{1}$, Ashley A. Rowden ${ }^{1,2}$ \\ ${ }^{1}$ School of Biological Sciences, University of Plymouth, Drake Circus, Devon PL4 8AA, United Kingdom \\ ${ }^{2}$ Present address: National Institute of Water and Atmospheric Research, PO Box 14-901, Kilbirnie, Wellington, New Zealand
}

\begin{abstract}
Within-bed variation of epiphytic algal assemblages was studied in 3 Zostera marina beds around Plymouth Sound (Devon, United Kingdom) in order to determine if distance from edge of bed affected the assemblage composition. Replicate seagrass samples were taken at 0, 1, 3 and $6 \mathrm{~m}$ along a transect running from the edge of each bed. Individual epiphytes were enumerated and placed into 6 'functional' groups: filamentous, foliose, corticated filamentous, corticated foliose, saccate and coralline. The abundance of each functional group did not vary with distance into each bed, nor was it related to measures of seagrass architecture or potential grazing pressure from gastropods. A positive relationship between amphipod abundance and total epiphytes suggest these crustaceans are influenced by epiphytes as an available substrate rather than exerting a grazing effect. Differences amongst beds, however, were evident for filamentous, corticated filamentous and coralline functional groups. These groups comprised $99 \%$ of all epiphytes, resulting in the total algal abundance being different amongst beds. Similarly, the assemblage composition of the epiphytes was consistent within each bed, but differed amongst all 3 beds. Overall, therefore, epiphytic abundance and composition was not affected by distance from the edge of the bed, seagrass architecture or grazing pressure within the bed, but existence of within-bed variation cannot be completely ruled out due to the comparatively low power of the analysis. The only significant variation occurred at the amongstbed level, probably due to variations in large-scale factors.
\end{abstract}

KEY WORDS: Epiphytes - Algae - Assemblage composition - Functional groups · Edge effects · Algal community

Resale or republication not permitted without written consent of the publisher

\section{INTRODUCTION}

Epiphytic algae utilise the surface of seagrass blades as a substrate for growth, the seagrass providing a habitat for increased light availability and water flow that allows optimum growth and supply of nutrients (Nelson \& Waaland 1997). Epiphytic algae can comprise between 24 and $67 \%$ of the total biomass of a seagrass bed (Penhale 1977, Kitting et al. 1984, Morgan \& Kitting 1984, Nelson \& Waaland 1997); primary production by epiphytes can be as low as $18 \%$ of the total bed (Penhale 1977), but can be so high that it exceeds that of the seagrass (Fry 1984). The epiphytic assemblage on seagrasses often consists of a large number of species displaying a variety of morphologies
(Milchakova 2000, Vanderklift \& Lavery 2000), so consequently epiphytic algal assemblage composition can be highly variable on both spatial (Kendrick \& Burt 1997, Lavery \& Vanderklift 2000a,b, Milchakova 2000, Vanderklift \& Lavery 2000) and temporal (Alcoverro et al. 1997, Kendrick \& Burt 1997, Reyes \& Sanson 1997, Cebrian et al. 1999, Milchakova 2000) scales.

Seagrass beds have long been recognised as areas of high faunal diversity and abundance compared with adjacent areas of bare soft sediment (Connolly 1994, Bostrom \& Bonsdorff 1997, Sheridan 1997). The increase in diversity has been related to many aspects of the seagrass habitat, such as shoot density (Webster et al. 1998), seagrass biomass (Heck \& Orth 1980, Attrill et al. 2000) and the structural complexity of the bed 
(Tolan et al. 1997). In these studies numerous physical measurements of the seagrass bed have been taken (e.g. shoot density, leaf length, sediment grain size) and compared with the associated faunal assemblage. Epiphytic algae biomass is often included within these characteristics, although there is generally no further indication of the types of algae and their assemblage composition within this category. The categorisation of epiphytic algae into one single figure, based solely on biomass, is also common in studies of the ecology of seagrass beds in relation to food webs and energy pathways (Penhale 1977, Morgan 1980, Fry 1984, Kitting et al. 1984, Fong et al. 2000, Hily et al. 2000), and studies into primary production and subsequent levels of productivity (Coleman \& Burkholder 1994, Lin et al. 1996, Nelson \& Waaland 1997).

Categorising epiphytic algae into a single group will disguise the variation that may occur within and amongst seagrass beds, and potentially confound investigations because of sampling artefacts associated with the species-area relationship (Attrill et al. 2000). Patterns of epiphytic algal assemblage composition have, therefore, largely been left unexplored. The lack of knowledge about different types of algae is not surprising, as the work involved in identification and measurement is considerable, and is not usually involved in the primary aims of the generally animalcentric studies. Despite this, a few papers have identified epiphytic algae to species level (e.g. Attrill et al. 2000) or categorised algae into functional groups (e.g. Lavery \& Vanderklift 2000a). The use of algal functional groups has been primarily used to examine the feeding behaviour and preferences of herbivorous macrofauna in a seagrass bed (e.g. Morgan \& Kitting 1984). However, the method provides a useful, prag-

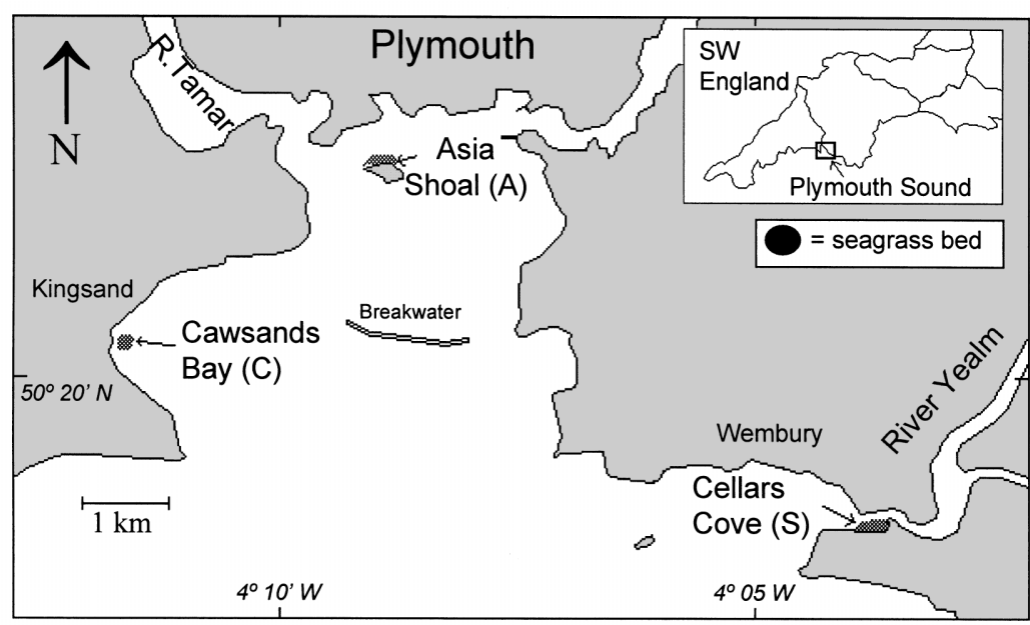

Fig. 1. The locations of the 3 Zostera marina sites in relation to Plymouth Sound, UK matic approach for the study of patterns in epiphytic algal assemblage composition.

The difference in epiphytic assemblage structure within and amongst beds has received relatively little attention (Kendrick \& Burt 1997, Milchakova 2000, Vanderklift \& Lavery 2000); in particular, investigations of any changes in assemblage composition that might occur in the vicinity of the seagrass-bed boundary appear to be lacking (but see Bell et al. 2001, Bowden et al. 2001). The influence of edge effects on assemblage structure in terrestrial patchy habitats has a long tradition and has revealed interesting ecological insights (e.g. Soulé 1986, Renhorn et al. 1997, Fagan et al. 1999). The aim of the present study is to test the null hypothesis that epiphyte assemblage structure does not vary with distance from the edge of a seagrass bed.

\section{MATERIALS AND METHODS}

Field sampling. Three seagrass beds were selected for sampling around the area of Plymouth Sound, Devon, United Kingdom (Fig. 1). All 3 seagrass beds are broadly comparable in that they are all composed of Zostera marina (L.), cover the same depth range (2 to $12 \mathrm{~m}$ ), are of similar size (30 to $50 \mathrm{~m}$ in diameter) and are situated in extreme outer-estuary locations with minimal influence of reduced salinity. The 3 sites were Cawsand Bay on the western side of Plymouth Sound $\left(50^{\circ} 20.0^{\prime} \mathrm{N}, 4^{\circ} 11.5^{\prime} \mathrm{W}\right)$, Cellars Cove at the mouth of the Yealm estuary $\left(50^{\circ} 18.5^{\prime} \mathrm{N}, 4^{\circ} 04.0^{\prime} \mathrm{W}\right)$, and Asia Shoal, north of Drakes Island, Plymouth Sound $\left(50^{\circ} 21.5^{\prime} \mathrm{N}, 4^{\circ} 09.3^{\prime} \mathrm{W}\right)$. Whilst the Yealm site is situated in an estuary mouth, the river flow here is very small and the site is effectively a marine location comparable with the sites in Plymouth Sound.

A preliminary survey using a framemounted drop-down video camera was undertaken on 13 September 2000 in order to determine the position and extent of the seagrass beds and the location of a suitable bed edge from which transects could be established. At each site, a transect was set perpendicular to the edge at a constant depth of $6 \mathrm{~m}$ (mid-tide). Along this transect, 3 replicate samples were taken at $0,1,3$, and $6 \mathrm{~m}$ from the edge of the bed. Samples were collected using SCUBA, and 1 site was sampled per day between 18 and 20 September 2000. Samples of the above-ground seagrass were collected from within plastic rings (diameter 
$24.5 \mathrm{~cm}$, area $0.047 \mathrm{~m}^{2}$ ) onto which a $500 \mu \mathrm{m}$ mesh bag was attached. The rings were placed haphazardly over the seagrass, up to $1 \mathrm{~m}$ perpendicular to each specific distance on the transect. All leaves within the ring were cut at their base level with the substratum, floated into the mesh bag, the ring removed and the bag shut to contain the sample. On the diving vessel, each sample was transferred to a labelled plastic bag and preserved in $99 \%$ alcohol.

Laboratory analysis. Plant architecture was quantified by counting the number of seagrass shoots and leaves present in each sample, and measuring the length and width of each seagrass leaf to the nearest $\mathrm{mm}$ with a tape measure (allowing total leaf area to be calculated). Epiphytic algae were identified as belonging to the functional groups proposed by Lavery \& Vanderklift (2000a). Only 6 of these authors' 8 functional groups were used: filamentous, foliose, corticated filamentous, corticated foliose and saccate; articulated coralline and encrusting coralline were combined into a single coralline group for simplicity. Cyanobacteria were omitted due to enumeration problems that would have been presented due to their size. Counting of individuals was completed under $40 \times$ magnification, and epiphytes counted in $10 \mathrm{~cm}$ segments from the base. Following algal identification and removal, total above-ground seagrass biomass (fresh weight) was recorded.

Prior to epiphyte identification and enumeration, seagrass samples were washed through a $500 \mu \mathrm{m}$ sieve, all species of gastropod and amphipod being removed from the residue and their abundance on each seagrass plant counted. Such counts were made to provide an analogue of potential grazing pressure, these groups being the main grazers on seagrass epiphytes present in Zostera marina beds (Thom et al. 1995, Kinlan et al. 1997, Nelson 1997, Kharlamenko et al. 2001).

Data analysis. To allow analysis of the epiphytic algal abundance and assemblage structure, the number of individuals from each functional group per $\mathrm{cm}$ of seagrass leaf was calculated by dividing the total abundance on the leaf sample by its total length. Resulting data were analysed by both univariate and multivariate statistical techniques. ANOVA (GMAV5 package) was performed on total and functional group abundances using a 2-factor orthogonal model, in which within-bed location is a fixed factor and bed is treated as a random factor. All data were tested using Cochran's $C$-test and transformed, $\ln (x+1)$, where necessary to correct for departures from normality. For all analyses the level of significance was set at $\alpha=0.05$. For significant results, Student-Newman-Keul's multiple range tests were employed in order to assess the significance of differences between pairs of sites.
Linear regression was used to investigate the relationship between epiphyte abundance and possible controlling variables such as plant architecture (number of shoots, number of leaves, seagrass area, seagrass biomass) and grazer abundance. All data were tested for normality before analysis (Shapiro-Wilk statistic) and transformed where necessary. The residuals of significant regressions were checked for normality (ShapiroWilk) and heteroscedasticity (examination of standardised residual plots).

The PRIMER software package (Clarke \& Warwick 2001) was used for multivariate analysis of the assemblage structure of the epiphytic algae. Data were double square-root-transformed (to reduce the influence of dominant taxa) and the Bray-Curtis index used to construct the similarity matrix. Similarities in epiphyte assemblage composition were displayed by constructing a dendrogram and ordination from the similarity matrix. The dendrogram was constructed using agglomerative, hierarchical clustering with group-averaging, whilst ordination used non-metric multidimensional scaling (n-MDS). Significant differences in assemblage composition between the a priori groupings of samples were investigated using a 2-way analysis of similarity (ANOSIM, Clarke \& Green 1988), the main species contributing to any dissimilarity between groupings being assessed using SIMPER (similarity percentages, Clarke 1993). To investigate which measured environmental variables (including grazer abundances) best explained the observed assemblage composition, the BIOENV procedure was utilised (Clarke \& Ainsworth 1993).

\section{RESULTS}

Average epiphytic abundance over all seagrass samples was 4.19 ind. $\mathrm{cm}^{-1}$. However, there was a large variation in the abundance of each functional group (Fig. 2). Filamentous algae were, on average, the most abundant with 2.03 ind $\mathrm{cm}^{-1}$, followed by encrusting coralline algae with 1.44 ind. $\mathrm{cm}^{-1}$. Cawsand Bay had the lowest overall abundance of algae (1.21 ind $\left.\mathrm{cm}^{-1}\right)$, and Cellars Cove had the highest $\left(7.96\right.$ ind. $\left.\mathrm{cm}^{-1}\right)$.

For both total abundance and abundance of each functional group, there was no significant difference in abundance with distance into the bed (Table 1). Amongst-bed variation, however, was significant for 3 functional groups: corticated filamentous, filamentous and coralline algae (Table 1). As these 3 groups made up $99 \%$ of all epiphytes, the total abundance of algal epiphytes amongst beds is also significantly different (all $p<0.01$ ). There were no significant differences in seagrass architectural parameters or gastropod abun- 

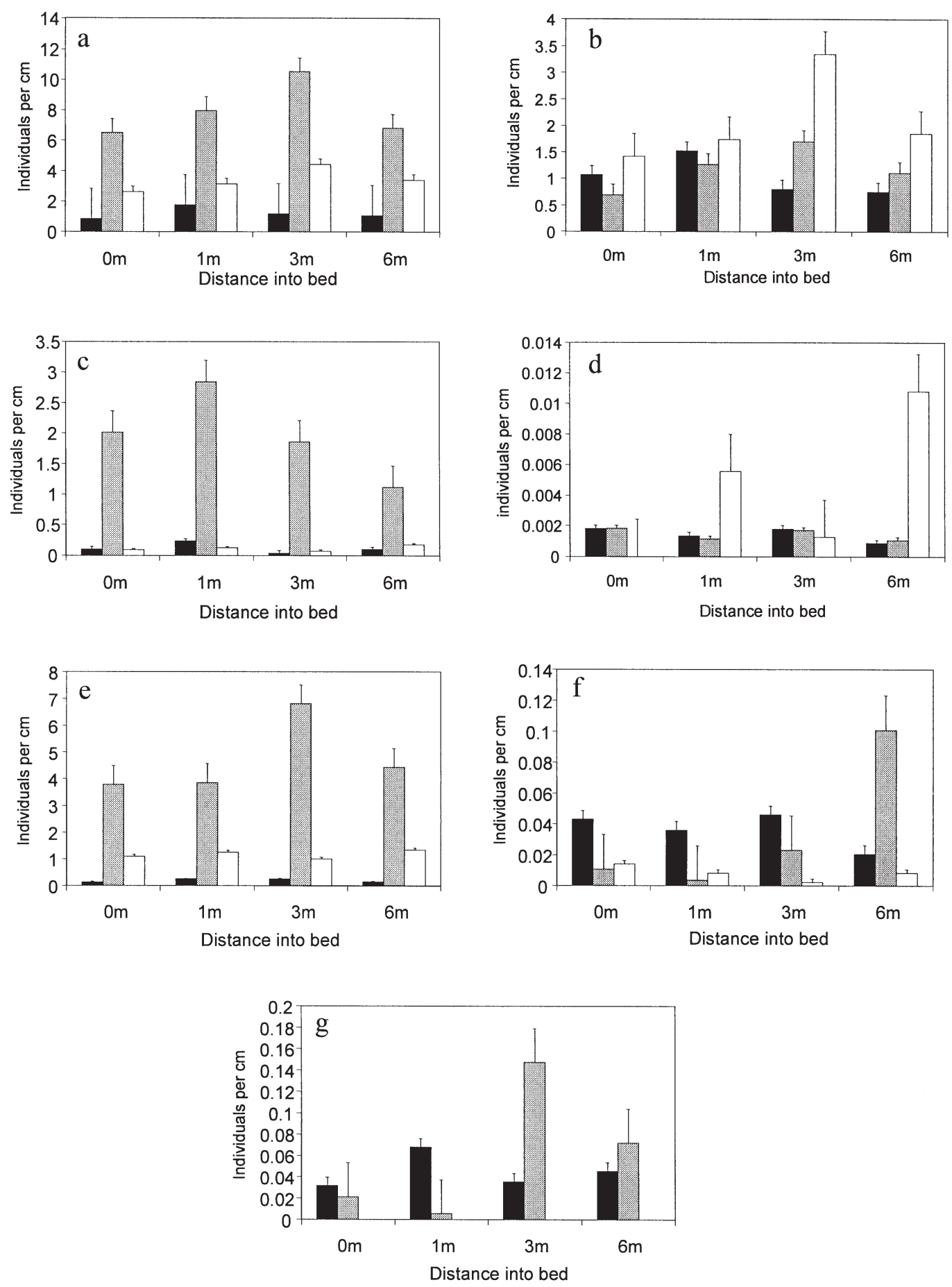

Fig. 2. Zostera marina. Abundance of each functional group at distance within and amongst Zostera marina beds. Total number of (a) epiphytes, (b) coralline algae, (c) corticated filaments, (d) corticated foliose, (e) filaments, (f) foliose, and (g) saccate.

Cawsand Bay $=$ dark shading, Cellars Cove $=$ light shading and Asia Shoal $=$ clear

dance within or amongst beds (all p >0.10, Table 2). Cawsand Bay, however, had a significantly lower abundance of amphipods than the other 2 sites (Table 2). No significant relationships were apparent between any aspect of epiphyte abundance and either seagrass architectural measures (linear regressions: all $p>0.20$ ) or gastropod abundance ( $\mathrm{p}=0.511)$, but a positive relationship with amphipod abundance was apparent (both variables transformed $\ln (x+1), \mathrm{r}^{2}=0.338, \mathrm{p}<0.001$, all residuals normal and homoscedastic). 
Table 1. Results of ANOVA on abundance of epiphyte functional groups within and amongst seagrass Zostera marina beds. $L n$ after functional type indicates $(\ln +1)$ transformation required. Corticated foliose algae were in low abundance, with all MS $<0.0001$, therefore not reported. Amphipod abundance was the only complementary variable varying significantly either within or amongst beds, therefore is reported

\begin{tabular}{|c|c|c|c|c|}
\hline Source & $\mathrm{df}$ & MS & $F$ & $\mathrm{p}$ \\
\hline \multicolumn{5}{|l|}{ Saccate } \\
\hline Site & 2 & 0.0122 & 2.08 & 0.147 \\
\hline Distance & 3 & 0.0033 & 0.68 & 0.594 \\
\hline Site $\times$ Distance & 6 & 0.0048 & 0.82 & 0.562 \\
\hline Residual & 24 & 0.0059 & & \\
\hline \multicolumn{5}{|l|}{ Foliose } \\
\hline Site & 2 & 0.0030 & 1.13 & 0.340 \\
\hline Distance & 3 & 0.0012 & 0.47 & 0.713 \\
\hline Site $\times$ Distance & 6 & 0.0026 & 1.00 & 0.451 \\
\hline Residual & 24 & 0.0026 & & \\
\hline \multicolumn{5}{|l|}{ Filamentous } \\
\hline Site & 2 & 67.98 & 48.73 & $<0.001$ \\
\hline Distance & 3 & 1.872 & 0.88 & 0.503 \\
\hline Site $\times$ Distance & 6 & 2.131 & 1.53 & 0.212 \\
\hline Residual & 24 & 1.395 & & \\
\hline \multicolumn{5}{|l|}{ Coralline $(L n)$} \\
\hline Site & 2 & 0.6742 & 7.64 & 0.003 \\
\hline Distance & 3 & 0.1262 & 1.87 & 0.236 \\
\hline Site $\times$ Distance & 6 & 0.0675 & 0.77 & 0.604 \\
\hline Residual & 24 & 0.0883 & & \\
\hline \multicolumn{5}{|c|}{ Corticated filamentous } \\
\hline Site & 2 & 13.58 & 17.19 & $<0.001$ \\
\hline Distance & 3 & 0.5728 & 1.19 & 0.390 \\
\hline Site $\times$ Distance & 6 & 0.4810 & 0.61 & 0.721 \\
\hline Residual & 24 & 0.7900 & & \\
\hline \multicolumn{5}{|l|}{ Total abundance } \\
\hline Site & 2 & 5.294 & 77.87 & $<0.001$ \\
\hline Distance & 3 & 0.0994 & 1.92 & 0.227 \\
\hline Site $\times$ Distance & 6 & 0.0517 & 0.76 & 0.608 \\
\hline Residual & 24 & 0.0680 & & \\
\hline \multicolumn{5}{|c|}{ Amphipod abundance } \\
\hline Site & 2 & 14.39 & 15.68 & $<0.001$ \\
\hline Distance & 3 & 0.8234 & 2.59 & 0.148 \\
\hline Site $\times$ Distance & 6 & 0.3182 & 0.35 & 0.905 \\
\hline Residual & 24 & 0.9183 & & \\
\hline
\end{tabular}

Table 2. Mean values $( \pm \mathrm{SE})$ for seagrass Zostera marina architectural parameters and potential grazer abundance for each site (per sample, $0.047 \mathrm{~m}^{2}$ ). Differences within and amongst beds were insignificant for all parameters except amphipod abundance (2-way ANOVA, all $\mathrm{p}>0.10$ ). $\mathrm{n}=12$ for all parameters. * Significantly different from other sites (SNK test)

\begin{tabular}{|lccc|}
\hline Parameter & Cawsand Bay & Cellars Cove & Asia Shoal \\
\hline Number of shoots & $4.58 \pm 1.11$ & $3.25 \pm 0.71$ & $4.00 \pm 0.72$ \\
Leaves per shoot & $3.63 \pm 0.15$ & $4.03 \pm 0.23$ & $3.82 \pm 0.15$ \\
Total leaf area $\left(\mathrm{cm}^{2}\right)$ & $313.33 \pm 87.91$ & $193.41 \pm 36.23$ & $399.32 \pm 80.59$ \\
Total plant biomass $(\mathrm{g})$ & $8.32 \pm 2.59$ & $7.70 \pm 2.67$ & $15.68 \pm 3.23$ \\
Gastropod abundance & $3.00 \pm 0.68$ & $5.50 \pm 1.40$ & $5.33 \pm 1.81$ \\
Amphipod abundance & $1.08 \pm 0.34^{*}$ & $16.42 \pm 4.75$ & $17.08 \pm 3.53$ \\
\hline
\end{tabular}

Multivariate analysis of the assemblage composition supported the results of the ANOVA. ANOSIM results indicated that there was no significant difference in composition between within-bed locations ( $\mathrm{r}=-0.031$, $\mathrm{p}=0.655$ ), whilst differences in epiphyte assemblage composition between each seagrass bed were significant $(\mathrm{r}=0.943, \mathrm{p}<0.001)$. The dendrogram and n-MDS ordination of the data clearly illustrate the patterns in assemblage composition, with samples from the sites forming 3 separate groupings in which no sub-grouping by distance from bed edge is apparent (Fig. 3). The Cellars Cove site (Yealm estuary) is clustered with one of the Plymouth Sound sites, the other site being in a separate cluster, suggesting that environmental conditions in the mouth of the Yealm do not result in a vastly different assemblage from those in Plymouth Sound. SIMPER analysis indicated that different functional groups contributed most to dissimilarity between each pair of beds (Table 3), reflecting the overall differences in assemblage composition amongst beds. None of the measured environmental parameters explained the assemblage patterns, the only measured variable that demonstrated a weak correlation being amphipod abundance (BIOENV analysis, $r=0.142$ ), reflecting the lower numbers recorded at Cawsand Bay (all other variables, $\mathrm{r}<0.06)$.

\section{DISCUSSION}

The abundance and composition of the sampled epiphytic algal assemblages showed no pattern of distribution or gradient of change relating to increasing distance from the edge of the seagrass bed and, additionally, no relationship with either measure of plant architecture or gastropod abundance. Amongstbed variation of epiphytic algae was considerable, despite the fact that the sites sampled were chosen for their apparent comparability. Clearly, failing to obtain a significant within-bed effect may be due to insufficient levels of replication at this scale, in what is potentially a highly variable system. Therefore, whilst it can be positively stated that amongst-bed variations were more pronounced than within-bed variations (which were not significant), the existence of within-bed patterns cannot be completely ruled out in the present study due to comparatively low power of the analysis. Nevertheless, the magnitude of the amongst-bed differences, when compared with within-bed differences, was unexpected, as the abun- 
dance and composition of epiphytic algae can potentially be influenced by a number of factors that have been shown to vary depending upon location within a seagrass bed.

Within a seagrass bed, biological factors such as herbivory are potentially the most important in structuring

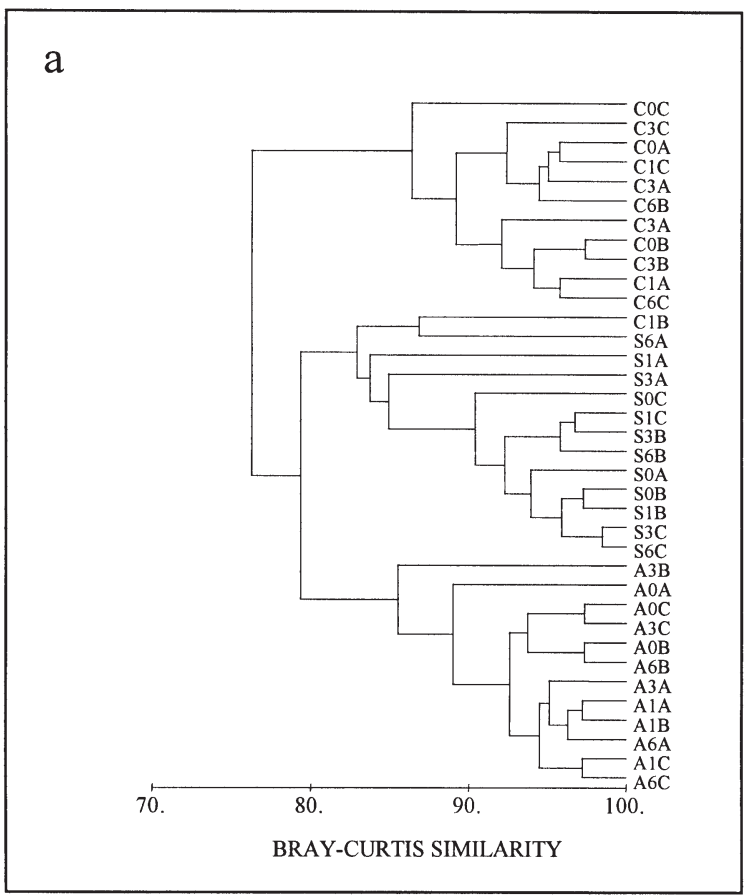

b

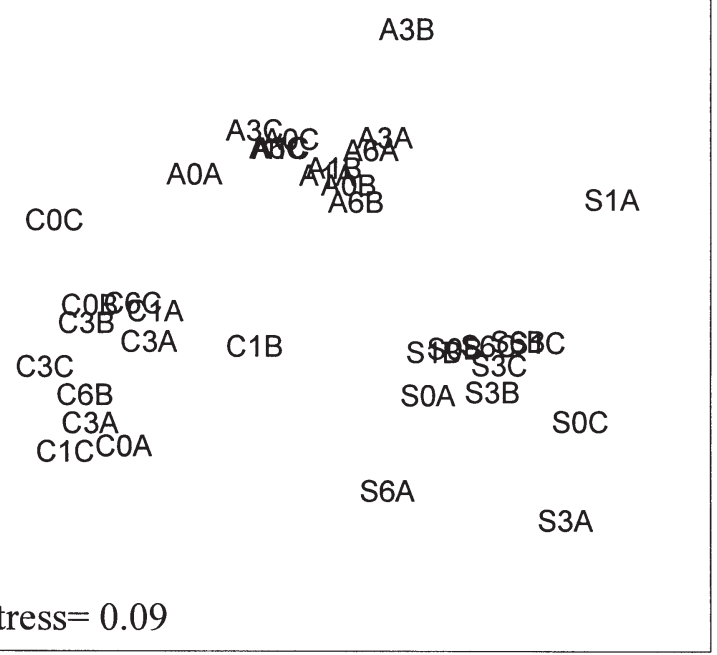

Fig. 3. Zostera marina. (a) Dendrogram of epiphyte assemblage data based on the Bray Curtis similarity index. Sample codes: $\mathrm{C}=$ Cawsand Bay, $\mathrm{S}=$ Cellars Cove and $\mathrm{A}=$ Asia Shoal. 0, 1, 3 and 6 correspond to distances (m) into bed. A, B and $\mathrm{C}$ represent the 3 replicates at each distance. (b) MDS ordination of the same data, see dendrogram for codes algal epiphyte assemblages. Many species of herbivore feed directly on the epiphytic algae as opposed to the seagrass (Thayer et al. 1978, Zimmerman et al. 1979, Morgan 1980, Fry 1984, Kitting et al. 1984, Morgan \& Kitting 1984, Jernakoff \& Nielson 1997, Hily et al. 2000), and the concentration of this herbivory has been shown to alter the abundance and community structure of the epiphytic algae (Alcoverro et al. 1997, Jernakoff \& Nielsen 1997, Fong et el. 2000). In an analogue of predation impact (Irlandi 1997, Bologna \& Heck 1999) it could be hypothesised that grazing pressure, and thus epiphyte algal assemblage composition, at the edge of beds may be different to that at further distances into the bed. In the present study, we attempted to give a measure of potential herbivory by enumerating the group of main algal grazers within these Zostera beds, namely the gastropods and amphipods. From our results, there were no significant differences in gastropod abundance within, or amongst, beds, the latter in contrast to the epiphyte results. However, gastropod grazing may potentially be affecting epiphyte abundance at a smaller scale (i.e. plant, Fong et al. 2000), but there was no significant linear relationship between epiphyte and gastropod abundance. Conversely, there was a significant positive relationship between amphipod abundance and total epiphyte density, the low levels of epiphytes in Cawsand reflected in significantly low amphipod abundance at this site. The positive nature of this relationship suggests that the amphipods are responding to the additional available habitat (Attrill et al. 2000) rather than exerting a grazing effect on the epiphyte assemblage, the density of amphipods being relative to the amount of algae present. Certainly, from our

Table 3. Results of SIMPER analysis, highlighting the 3 epiphyte algal functional groups contributing most to dissimilarity between assemblage composition in each pair of seagrass Zostera marina beds. Data were 4th-root-transformed prior to analysis

\begin{tabular}{|lrc|}
\hline $\begin{array}{l}\text { Bed pair } \\
\text { Algal functional group }\end{array}$ & $\begin{array}{c}\text { Average } \\
\text { term }\end{array}$ & $\begin{array}{c}\% \\
\text { contribution }\end{array}$ \\
\hline Cawsand vs Cellars Cove & & \\
Filamentous & 10.84 & 38.71 \\
Corticated filamentous & 8.21 & 29.35 \\
Foliose & 2.76 & 9.87 \\
Cawsand vs Asia Shoal & & \\
Saccate & 7.07 & 29.40 \\
Filamentous & 6.17 & 25.66 \\
Encrusting & 3.75 & 15.59 \\
Cellars Cove vs Asia Shoal & & \\
Corticated filamentous & 7.85 & 31.12 \\
Filamentous & 5.56 & 22.04 \\
Saccate & 4.78 & 18.96 \\
\hline
\end{tabular}


results there is no evidence that herbivore pressure was affecting the epiphyte assemblage over the spatial scale examined, although potential grazing pressure by alternative herbivores which were not enumerated (e.g. fish) remains a possibility.

Environmental factors in the seagrass bed can also influence the epiphytic assemblage, such as light levels (Ruiz \& Romero 2001) and small-scale hydrodynamics (Kendrick \& Burt 1997). Light levels and water current characteristics were not directly assessed in the present study for they are difficult and costly to effect in practice; however, the measures made of plant architecture can be used as proxy indicators in order to interpret the results. It is feasible that epiphytes at the edge of beds may experience less shading than those in the middle, particularly if there are changes in self-shading concomitant with variations in seagrass physical architecture with distance from the bed edge (Cebrian et al. 1999). At the study sites, however, neither shoot density nor number of leaves exhibited any significant increase or variation along the sample transect. Thus, any associated light variability does not appear to be influencing the amount, or composition, of the epiphyte assemblage within the seagrass beds. Similarly, any reductions in water flow that occur with increasing distance into a seagrass bed (Fonseca \& Bell 1998), and with changes in shoot/leaf density (Eckman 1987), are not reflected in any observable differences in the epiphytic algae assemblage. Clearly, further studies using direct measures of light and current are required before any firm conclusions can be drawn about the apparent lack of influence of these variables on assemblage composition within a seagrass bed.

However, the similarity of the epiphytic assemblage observed within the seagrass beds of Plymouth Sound is consistent with some results from the few relevant recent studies. Vanderklift \& Lavery (2000), using data that held shoot density constant, found that within-bed samples separated by $10 \mathrm{~s}$ of $\mathrm{cm}$ displayed a homogenous algal epiphyte assemblage structure. Nonetheless, differences between assemblages 1 to $10 \mathrm{~m}$ apart were observed in the majority of samples analysed from within the 2 beds studied (Vanderklift \& Lavery 2000). Attrill et al. (2000) found that epiphytic algal assemblage composition within a single seagrass bed was not significantly different, despite sample groups being taken from areas of differing shoot density (10s of $m$ apart).

Amongst-bed differences in epiphytic algae of seagrass, as observed in the present study, have been found in previous studies on Posidonia species. Two seagrass beds, $8 \mathrm{~km}$ apart, were examined by Kendrick \& Burt (1997), who found distinct epiphytic assemblages at each site. However, the 2 sites studied contrasted in environmental setting, one being offshore-exposed and the other inshore-protected (Kendrick \& Burt 1997). In a study on a similar scale to the present one, but which concerned a more morphologically complex seagrass species in oligotrophic waters, Vanderklift \& Lavery (2000) found differences in epiphyte assemblage structure between 2 areas of seagrass on the same sand bank that were only $2 \mathrm{~km}$ apart. Despite selecting for seagrass beds of a similar physical arrangement in relatively close proximity (4 to $9 \mathrm{~km}$ apart) for the present study, it appears that environmental conditions at each site were probably dissimilar enough to result in marked amongst-bed differences in epiphytic algal assemblage composition. Potential controlling factors include nutrient levels, light levels (through variations in turbidity) and particularly local hydrodynamics influencing the settlement and dispersal of algae (Coleman \& Burkholder 1994, Harwell \& Orth 1999, Moore \& Wetzel 2000). If the amongst-site variation in epiphytic algae is due to a single factor, or more likely a combination of many, it is impossible from this study to state categorically what these factors are. Similarly, studies which have examined spatial patterns of macroinvertebrate assemblages associated with seagrass beds have found that within-bed differences in composition are minor compared to those observable amongst beds. Even when beds are separated by only kilometres in areas of apparently similar environmental conditions, the factors responsible for the distinctions remain largely unidentified (Turner et al. 1999, Bowden et al. 2001). Therefore, the amongst-bed factors appear to have a far greater influence on assemblage composition than variation in location from the edge of a bed, and further research addressing variability at this scale should be a priority in seagrass research.

\section{CONCLUSIONS}

The findings of the present study support the few previous investigations in this area, which have concluded that epiphytic algal abundance and distribution is not a constant factor amongst seagrass beds. More importantly, however, the results indicate that the within-bed algal epiphyte assemblage may potentially be considered uniform, with no edge effects being detectable for epiphyte assemblages at the scale of metres, though further studies incorporating seasonal fluctuations and increased replication at the lowest scale would be needed to confirm this. The causes of the larger-scale variation are likely to be related to a number of environmental factors, which to varying degrees will influence the success of epiphytic species in colonising (e.g. hydrography) and persisting (e.g. 
grazing pressure) on seagrass blades. The scale of this environmental variation would appear to be the factor best explaining the consistency in abundance and composition of epiphytic algae within a seagrass bed. Over the distance of a single bed, any variation or gradient in these conditions will be very small or negligible, and does not produce changes in the epiphytic assemblage, resulting in the homogenous assemblage found within each of the 3 beds examined, although again this requires further work to confirm the lack of within-bed patterns. Seagrass beds separated by several kilometres, as in this study, will apparently be subjected to unique environmental conditions resulting in an equally distinct epiphytic algae assemblage. Thus, the results of this study provide further evidence for the importance of scale when devising and analysing experiments on seagrass beds. This consistency across independent studies is an important result for future examinations of spatial pattern in epiphytic algal assemblages. The results of this study preliminarily suggest that epiphytes of a single seagrass bed can be treated justifiably as a homogenous assemblage, whilst the assemblages of separate beds should be considered a priori as being discrete.

Acknowledgements. We would like to extend our thanks to Oliver Twydell, Roger Haslem and Richard Ticehurst for diving and sampling assistance, Sue Syson and the Diving and Sailing Centre for technical assistance and Emma Jackson for advice and support (all from the University of Plymouth). We also would like to acknowledge the input of several anonymous referees whose comments improved the manuscript.

\section{LITERATURE CITED}

Alcoverro T, Duarte CM, Romero J (1997) The influence of herbivores on Posidonia oceanica epiphytes. Aquat Bot 56: 93-104

Attrill MJ, Strong JA, Rowden AA (2000) Are macroinvertebrate communities influenced by seagrass structural complexity? Ecography 23:114-121

Bell SS, Brooks RA, Robbins BD, Fonseca MS, Hall MO (2001) Faunal response to fragmentation in seagrass habitats: implications for seagrass conservation. Biol Conserv 100: 115-123

Bologna PAX, Heck KL (1999) Differential predation and growth rates of bay scallops within a seagrass habitat. J Exp Mar Biol Ecol 239:299-314

Bostrom C, Bonsdorff E (1997) Community structure and spatial variation of benthic invertebrates associated with Zostera marina (L.) beds in the Northern Baltic Sea. J Sea Res 37:153-166

Bowden DA, Rowden AA, Attrill MJ (2001) Effect of patch size and in-patch location on the infaunal macroinvertebrate assemblages of Zostera marina seagrass beds. J Exp Mar Biol Ecol 259:133-154

Cebrian J, Enriquez S, Fortes M, Agawin N, Vermaat JE, Duarte CM (1999) Epiphyte accrual on Posidonia oceanica (L.) Delile leaves: implications for light absorption. Bot Mar 42:123-128
Clarke KR (1993) Non-parametric multivariate analyses of changes in community structure. Aust J Ecol 18:117-143

Clarke KR, Ainsworth M (1993) A method of linking multivariate community structure to environmental variables. Mar Ecol Prog Ser 92:205-219

Clarke KR, Green RH (1988) Statistical design and analysis for a 'biological effects' study. Mar Ecol Prog Ser 46: $213-226$

Clarke KR, Warwick RM (2001) Changes in marine communities: an approach to statistical analysis and interpretation. Primer-E, Plymouth Marine Laboratory, Plymouth

Coleman VL, Burkholder JM (1994) Community structure and productivity of epiphytic macroalgae on eelgrass (Zostera marina L.) under water column nitrate enrichment. J Exp Mar Biol Ecol 179:29-48

Connolly RM (1994) Removal of seagrass canopy: effects on small fish and their prey. J Exp Mar Biol Ecol 184:99-110

Eckman JE (1987) The role of hydrodynamics in recruitment, growth and survival of Argopecten irradians (L.) and Anomia simplex (Dorbigny) within eelgrass meadows. J Exp Mar Biol Ecol 106:165-191

Fagan WE, Cantrell RS, Cosner C (1999) How habitat edges change species interactions. Am Nat 153:165-182

Fong CW, Lee SY, Wu RS (2000) The effects of epiphytic algae and their grazers on the intertidal seagrass Zostera japonica. Aquat Bot 67:251-261

Fonseca MS, Bell SS (1998) Influence of physical setting on seagrass landscapes near Beaufort, North Carolina, USA. Mar Ecol Prog Ser 171:109-121

Fry $\mathrm{B}(1984){ }^{13} \mathrm{C} /{ }^{12} \mathrm{C}$ ratios and the trophic importance of algae in Florida Syringodium filiforme seagrass meadows. Mar Biol 79:11-19

Harwell MC, Orth RJ (1999) Eelgrass (Zostera marina L.) seed protection for field experiments and implications for largescale restoration. Aquat Bot 64:51-61

Heck KL, Orth RJ (1980) Seagrass habitats: the roles of habitat complexity, competition and predation in structuring associated fish and motile macroinvertebrate assemblages. In: Kennedy VS (ed) Estuarine perspectives. Academic Press, New York, p 449-464

Hily C, Connan S, Raffin C, Le Mercier A (2000) Quantification of the grazing activity on seagrass epiphyton with a new methodological approach: first application in Zostera marina meadows. Biol Mar Medit 7:223-226

Irlandi EA (1997) Seagrass patch size and survivorship of an infaunal bivalve. Oikos 78:511-518

Jernakoff P, Nielson J (1997) The relative importance of amphipod and gastropod grazers in Posidonia sinuosa meadows. Aquat Bot 56:183-202

Kendrick GA, Burt JS (1997) Seasonal changes in epiphyte macro-algae assemblages between offshore exposed and inshore protected Posidonia sinuosa Cambridge et Kuo seagrass meadows, Western Australia. Bot Mar 40: $77-85$

Kharlamenko VI, Kiyashko SI, Imbs AB, Vyshkvartzev DI (2001) Identification of food sources of invertebrates from the seagrass Zostera marina community using carbon and sulfur stable isotope ratio and fatty acid analyses. Mar Ecol Prog Ser 220:103-117

Kinlan B, Duffy E, Cebrian J, Hauxwell J, Valiela I (1997) Control of periphyton on Zostera marina by the eastern mudsnail, Ilyanassa obsoleta (Say), in a shallow temperate estuary. Biol Bull (Woods Hole) 193:286-287

Kitting CL, Fry B, Morgan MD (1984) Detection of inconspicuous epiphytic algae supporting food webs in seagrass meadows. Oecologia 62:145-149

Lavery P, Vanderklift M (2000a) Comparisons of spatial pat- 
terns in seagrass epiphyte assemblages using species and functional group data. Biol Mar Medit 7:251-254

Lavery P, Vanderklift M (2000b) Differences in spatial patterns in assemblages of epiphytic macroalgae between seagrass hosts. Biol Mar Medit 7:294-297

Lin HJ, Nixon SW, Taylor DI, Granger SL, Buckley BA (1996) Responses of epiphytes on eelgrass, Zostera marina L., to separate and combined nitrogen and phosphorus enrichment. Aquat Bot 52:243-258

Milchakova NA (2000) The dynamics of the encrusting layer on Zostera marina L. leaves in Sevastopol Bay. Biol Mar Medit 7:255-258

Moore KA, Wetzel RL (2000) Seasonal variations in eelgrass (Zostera marina L.) responses to nutrient enrichment and reduced light availability in experimental ecosystems. J Exp Mar Biol Ecol 244:1-28

Morgan MD (1980) Grazing and predation of the grass shrimp Palaemonetes pugio. Limnol Oceanogr 25:896-902

Morgan MD, Kitting CL (1984) Productivity and utilisation of the seagrass Halodule wrightii and its attached epiphytes. Limnol Oceanogr 29:1066-1076

Nelson TA (1997) Epiphyte-grazer interactions on Zostera marina (Anthophyta: Monocotyledones): effects of density on community function. J Phycol 33:743-752

Nelson TA, Waaland JR (1997) Seasonality of eelgrass, epiphyte, and grazer biomass and productivity in subtidal eelgrass meadows subjected to moderate tidal amplitude. Aquat Bot 56:51-74

Penhale PA (1977) Macrophyte epiphyte biomass and productivity in an eelgrass (Zostera marina L.) community. J Exp Mar Biol Ecol 26:211-224

Renhorn KE, Esseen PA, Palmqvist K, Sundberg B (1997) Growth and vitality of epiphytic lichens. 1. Responses to microclimate along a forest edge-interior gradient. Oecologia 109:1-9

Reyes J, Sanson M (1997) Temporal distribution and repro-

Editorial responsibility: Otto Kinne (Editor),

Oldendorf/Luhe, Germany ductive phenology of the epiphytes on Cymodocea nodosa leaves in the Canary Islands. Bot Mar 40:193-201

Ruiz JM, Romero J (2001) Effects of in situ experimental shading on the Mediterranean seagrass Posidonia oceanica. Mar Ecol Prog Ser 215:107-120

Sheridan P (1997) Benthos of adjacent mangrove, seagrass and nonvegetated habitats in Rookery Bay, Florida, USA. Estuar Coast Shelf Sci 44:455-469

Soulé MJ (1986) Conservation, the science of scarcity and diversity. Sinauer, Sunderland

Thayer GW, Parker PL, LaCroix MW, Fry B (1978) The stable carbon isotope ratio of some components of an eelgrass, Zostera marina, bed. Oecologia 35:1-12

Thom R, Miller B, Kennedy M (1995) Temporal patterns of grazers and vegetation in a temperate seagrass system. Aquat Bot 50:201-205

Tolan JM, Holt SA, Onuf CP (1997) Distribution and community structure of ichthyoplankton in Laguna Madre seagrass meadows: potential impact of seagrass species change. Estuaries 20:450-464

Turner SJ, Hewitt JE, Wilkinson MR, Morrisey DJ, Thrush SF, Cummings VJ, Funnell G (1999) Seagrass patches and landscapes: the influence of wind-wave dynamics and hierarchical arrangements of spatial structure on macrofaunal seagrass communities. Estuaries 22: 1016-1032

Webster PJ, Rowden AA, Attrill MJ (1998) Effect of shoot density on the infaunal macroinvertebrate community within a Zostera marina seagrass bed. Estuar Coast Shelf Sci 47: 351-357

Vanderklift M, Lavery P (2000) Patchiness in assemblages of epiphytic macroalgae on Posidonia coriacea at a hierarchy of spatial scales. Mar Ecol Prog Ser 192:127-135

Zimmerman R, Gibson R, Harrington J (1979) Herbivory and detritivory among Gammaridean amphipods from a Florida seagrass community. Mar Biol 54:41-47

Submitted: January 23, 2002; Accepted: December 3, 2002 Proofs received from author(s): February 20, 2003 